\title{
ENVIRONMENTAL DRIVERS OF FISH ASSEMBLAGES FROM THE SHALLOW INFRALITTORAL AREAS OF THE PARANAGUÁ BAY, SOUTHERN BRAZIL
}

\author{
Paula Nakayama ${ }^{1}$, Alberto Carvalho Peret ${ }^{1}$, Johnatas Adelir-Alves ${ }^{2,3 *}$, Olimpio Rafael \\ Cardoso ${ }^{2,3}$, Marcelo Renato Lamour ${ }^{4}$ \& Henry Louis Spach ${ }^{3}$
}

${ }^{1}$ Universidade Federal de São Carlos, Departamento de Hidrobiologia, Rodovia Washington Luís, Km 235, CP 676, CEP: 13565-905. São Carlos, SP, Brazil.

${ }^{2}$ Universidade Federal do Paraná, Setor de Ciências Biológicas, Programa de Pós-Graduação em Zoologia, Avenida Cel Francisco H. Santos, s/n, Jardim das Américas, CEP: 81531-980. Curitiba, PR, Brazil.

${ }^{3}$ Universidade Federal do Paraná, Centro de Estudos do Mar, Laboratório de Ecologia de Peixes, Av. Beira-mar, s/n, CP 61, CEP: 83255-976. Pontal do Sul, Pontal do Paraná, PR, Brazil.

${ }^{4}$ Universidade Federal do Paraná, Centro de Estudos do Mar, Laboratório de Oceanografia Geológica, Av. Beira-mar, s/n CP 61, CEP: 83255-976. Pontal do Sul, Pontal do Paraná, PR, Brazil.

E-mails: pnakayama@gmail.com; peret@ufscar.br; johnatas_alves@yahoo.com (*corresponding author); rafael. bioufrgs@gmail.com; mlamour@ufpr.br; henry@ufpr.br

\begin{abstract}
The composition of estuarine fish fauna is dynamic and complex. Despite the variation in fish fauna in estuaries, it is possible to observe some species associated with microhabitats. The assemblage composition of these communities is apparently derived from habitat selection. The aim of this study was to assess the structure of the demersal fish fauna of the Paranaguá Bay and its relationship with biotic and abiotic factors. To this end, monthly collections were conducted using an otter trawl, from October 1999 to September 2000, at five sites in the shallow infralittoral. Biotic (organic matter, and invertebrates) and abiotic factors (salinity, temperature, $\mathrm{pH}$, dissolved oxygen, seston, and nutrients) were recorded during sampling. A total of 6,623 individuals were captured, belonging to 2 species of Chondrichthyes and 53 species of Actinopterygii (26 families). Sciaenidae was the most representative in terms of richness, with 11 species, and Ariidae was the most representative in terms of abundance. The catfish Cathorops spixii was the most abundant species, representing $21 \%$ of the entire catch. There were significant differences in the composition and abundance of the fish fauna among the studied areas, as evidenced by the ShannonWiener diversity index. Such differences seem to be related to the complexity of habitats, which occur due to different types of bottom cover found at each sampling site. The abiotic variables indicated little influence on the structure of the fish assembly. These results contribute to a better understanding of the fish fauna from the shallow infralittoral areas of the Paranaguá Bay, and provide data to decision makers for better implementation of management and conservation measures.
\end{abstract}

Keywords: abiotic factors; biotic factors; conservation; estuarine fishes; fish assemblage.

\section{INTRODUCTION}

The Paranaguá Estuarine Complex (PEC) has been classified as a coastal plain estuary (Lessa et al.
2000), and is the most important estuary at the northern coast of Paraná state in the southern region of Brazil due to its size and water flow (Lana et al. 2001) and considered a Natural World 
Heritage site (UNESCO, 1999). The region of PEC has approximately $600 \mathrm{~km}^{2}$ and includes extensive areas of mangrove forests, sandy beaches and rocky islands (Noernberg et al. 2004). This estuarine complex is ecologically and socioeconomically important, yet anthropogenic activities (e.g. habitat loss, environmental pollution, introduction of nonnative species, and overfishing), have seriously threatened the biodiversity of this important ecosystem (Passos et al. 2012, Possatto et al. 2017).

Estuaries are environments with exceptional productivity, characterized by large fluctuations of abiotic factors (e.g., temperature, salinity, and oxygen concentration), leading to a highly dynamic and complex fish assemblage in these environments (Elliott \& Hemingway 2002). Fish respond to variations in the environment through physiological adaptations, which allow them to tolerate environmental stresses, or by moving to regions where conditions are more favorable. Other elements influencing the composition of the fish fauna are biotic factors (e.g. reproduction, feeding, and interspecific interactions), as well as external conditions such as water pollution (Barbier et al. 2011, Elliott \&Whitfield 2011, Vilar et al. 2011).

Despite the variable composition of fish fauna being influenced environmental conditions (Elliott etal.2007), it is possible to observe some populations associated with microhabitats (Alofs \& Polivka 2004). The individuality of these communities is apparently derived from habitat selection (Elliott \& Hemingway 2002). Although many of the common species (both resident and transient) are found throughout the estuary and are considered generalist in terms of habitat selection, finer scale observations of their distributions generally show clearly defined centers of abundance (Elliott \& Whitfield 2011, Potter et al. 2015).

Seasonal and spatial changes in abiotic and biotic factors influence composition, structure, the spatial and temporal distribution of the ichthyofauna in estuaries (Cattani et al. 2020), and this relationship must be considered in the studies to gain a better understanding of the estuarine fish assemblage. Knowing the relationship between the fish assemblage and environmental conditions is fundamental in the ecological understanding of estuarine ecosystems (Barletta \& Blaber 2007, Potter et al. 2015). The fish fauna is considered as an environmental indicator, helping protection measures in these ecosystems (Elliott \& Whitfield 2011).

Thus, we aimed to examine the composition of the demersal fish fauna of the shallow infralittoral of the Paranaguá Bay, southern Brazil, and identify the biotic and abiotic factors related to the composition of the fish assemblage.

\section{MATERIAL AND METHODS}

\section{Paranaguá Estuarine Complex}

The Paranaguá Estuarine Complex (PEC) is influenced by river input and the biggest discharges correspond strictly with the rainy period that occurs between spring and summer months (Lana et al. 2001, Mantovanelli et al. 2004). These inflows, as well as anthropic activities, especially dredging, influence processes related to water-column stratification, salinity intrusion, sediment supply, and the turbidity maximum zone. The maximum amplitude of the tide can reach $2.0 \mathrm{~m}$ with an average of $0.84 \mathrm{~m}$, as long as the tidal variation amplitudes vary around $1.5 \mathrm{~m}$ (Lamour et al. 2004, Cattani \& Lamour 2016). The more intense winds occur from south, mainly in the winter months (July and August) (Nêmes \& Marone 2013). In this case, the bathymetry acts as an important obstacle to the waves progressing from the inner continental shelf to the outer estuary (mouth region), where dissipation of energy occurs over the shallow tidal delta (<3 m depth) (Lamour et al. 2007).

\section{Study area and data collection}

The present study was carried out at five sites (Figure 1) located in the euryhaline sector of PEC (Netto \& Lana 1997). Fish samples were collected monthly between October 1999 and September 2000. We used otter trawls, with lead-ahead opening length of $8 \mathrm{~m}$, length of $6.6 \mathrm{~m}$, mesh size of $1 \mathrm{~cm}$ in the body and cod end, and two flat rectangular otter boards $(0.70 \mathrm{~m} \times 0.47 \mathrm{~m}$ and $8 \mathrm{~kg}$ each$)$, in monthly trawls in quadrature high tide, lasting 20 minutes each. All fish caught were kept on ice and transported to the laboratory, where they were counted and identified to the species level, when possible (Figueiredo \& Menezes 1978, 1980, 2000, Menezes \& Figueiredo 1980, 1985). The bottom cover at each sampling site was qualitatively described. During fieldwork, samples of organic matter and invertebrates were collected, and categorized as presence and absence 


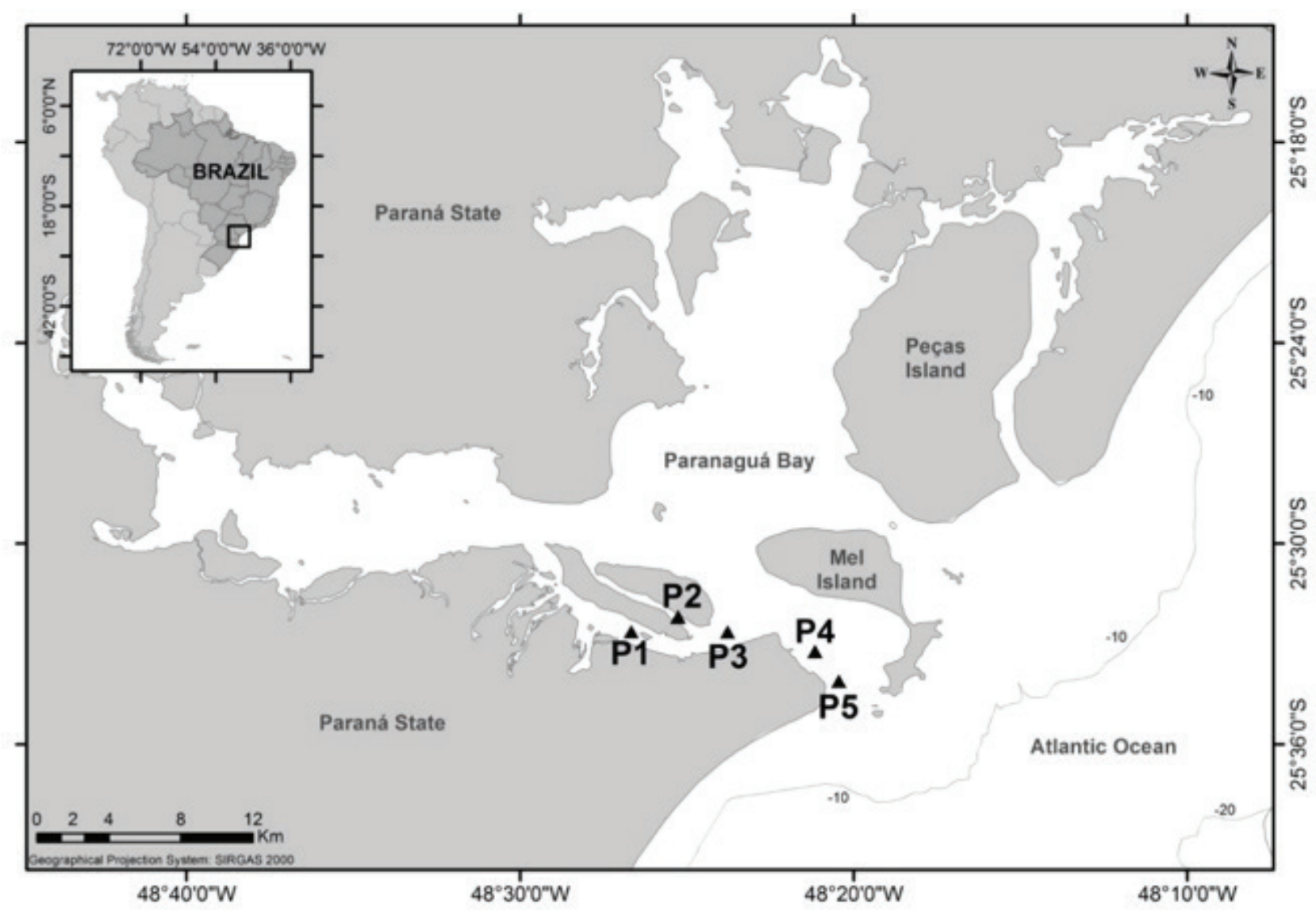

Figure 1. Map of Paranaguá Bay estuarine complex showing the sampling sites (shallow infralittoral). Gamboa dos Papagaios (P1), Gamboa do Sucuriu (P2), Gamboa do Baguaçu (P3), Ponta do Poço (P4) and Pontal do Sul (P5).

at each sampling site. The invertebrates were identified by specialists, from the Center of Sea Studies (CEM/UFPR).

The fish were classified into five estuarineuse functional groups (e.g. marine stragglers, marine migrants, estuarine residents, estuarine migrants, and semi-catadromous) (Elliott et al. 2007), and into geographic distribution categories: Circumtropical (CT), Trans-Atlantic (TA - Western and Eastern Atlantic Ocean), Western Atlantic (WA Northern and Southern Atlantic Ocean), Southwest Atlantic (SWA - ranging from Northern Brazil to Argentina), Southern Southwest Atlantic (SSWA - Southeastern and Southern Brazil, Uruguay and Argentina), Caribbean (CA - ranging from Florida to Venezuela), Brazilian Province (BR - ranging from the Orinoco River Delta in Venezuela to the State of Santa Catarina in Brazil, and Eastern Pacific (EP) (Briggs \& Bowen 2012, Fricke et al. 2020, Froese \& Pauly 2020). Species were also classified according to the national and global status of conservation, proposed by the Brazilian Ministry of Environment (MMA 2014) and the International Union for
Conservation of Nature categories (IUCN 2020), respectively.

Water samples at each sample site were taken near the bottom with a Van Dorn bottle, to determine $\mathrm{pH}$, dissolved oxygen, seston (suspended matter), and nutrients. Salinity and temperature were recorded with a STD SENSORDATA-SD200. Samples for $\mathrm{pH}$ determination, and for seston and nutrient analyses were stored in Styrofoam box with ice and transported to the laboratory. The $\mathrm{pH}$ was measured using a potentiometer INGOLD-206. Seston analysis was performed after filtration through Whatman GF/C filter, and refrigeration (Strickland \& Parsons 1972). Samples for determination of oxygen content were fixed in situ and kept in a dark container. In the laboratory, they were analyzed by the Winkler method. Concentrations of nitrate, nitrite, ammonium (inorganic nitrogen), phosphate, and silicate were determined by colorimetric techniques (Grasshoff et al. 1983). 


\section{Data analysis}

Environmental variables and fish abundance data were analyzed for normality and homoscedasticity, by the Shapiro-Wilk's and Levene tests, respectively. When necessary, the data were transformed $(\ln +1)$ (Zar 1996). Environmental variables were tested using ANOVA $(p<0.05)$ and differences were further explored with Tukey's post hoc tests. The Shannon-Wiener $\left(\mathrm{H}^{\prime}\right)$ diversity index (Shannon \& Wiener 1963) was used to describe the community structure by applying the Student's t-test to check the significance of the difference between them (Zar 1996).

The canonical discriminant analysis (CDA) was applied to describe the five sampling sites in relation to the composition of the fish fauna. The same analysis was applied to identify the differences between sampling sites based on environmental variables (Legendre \& Legendre 1983).

\section{RESULTS}

A total of 6,623 specimens of fish belonging to 55 species and 26 families were caught. One Actinopterygii was identified only to the level of genus (Citharichthys sp.). The catfish Cathorops spixii was the most abundant species, comprising $21 \%$ of the total catch. Other numerically important species were Anisotremus surinamensis (12\%), Prionotus punctatus (7 \%), Etropus crossotus (7 \%), Chaetodipterus faber (6\%) and Chloroscombrus chrysurus (6\%). These six most abundant species represented $59 \%$ of the entire catch and were present at the five sampling sites. Sciaenidae and Engraulidae were the most representative families in terms of richness, with 11 and 5 species, respectively (Table S1).

In the CDA, the differences in the species composition between the sampling sites are shown. The first two vectors were responsible for $96.52 \%$ of the data variance (Figure 2). The values of the Shannon-Wiener $\left(\mathrm{H}^{\prime}\right)$ diversity index in the Gamboa dos Papagaios, Gamboa do Sucuriu, Gamboa do Baguaçu and Ponta do Poço sites were high and not significantly different from each other. Pontal do Sul presented a low diversity, statistically different from the other sites (Table S2).

Gamboa do Sucuriu has a peculiar benthic formation with a large variety of organisms such as sponges (Craniella cranium), bryozoans

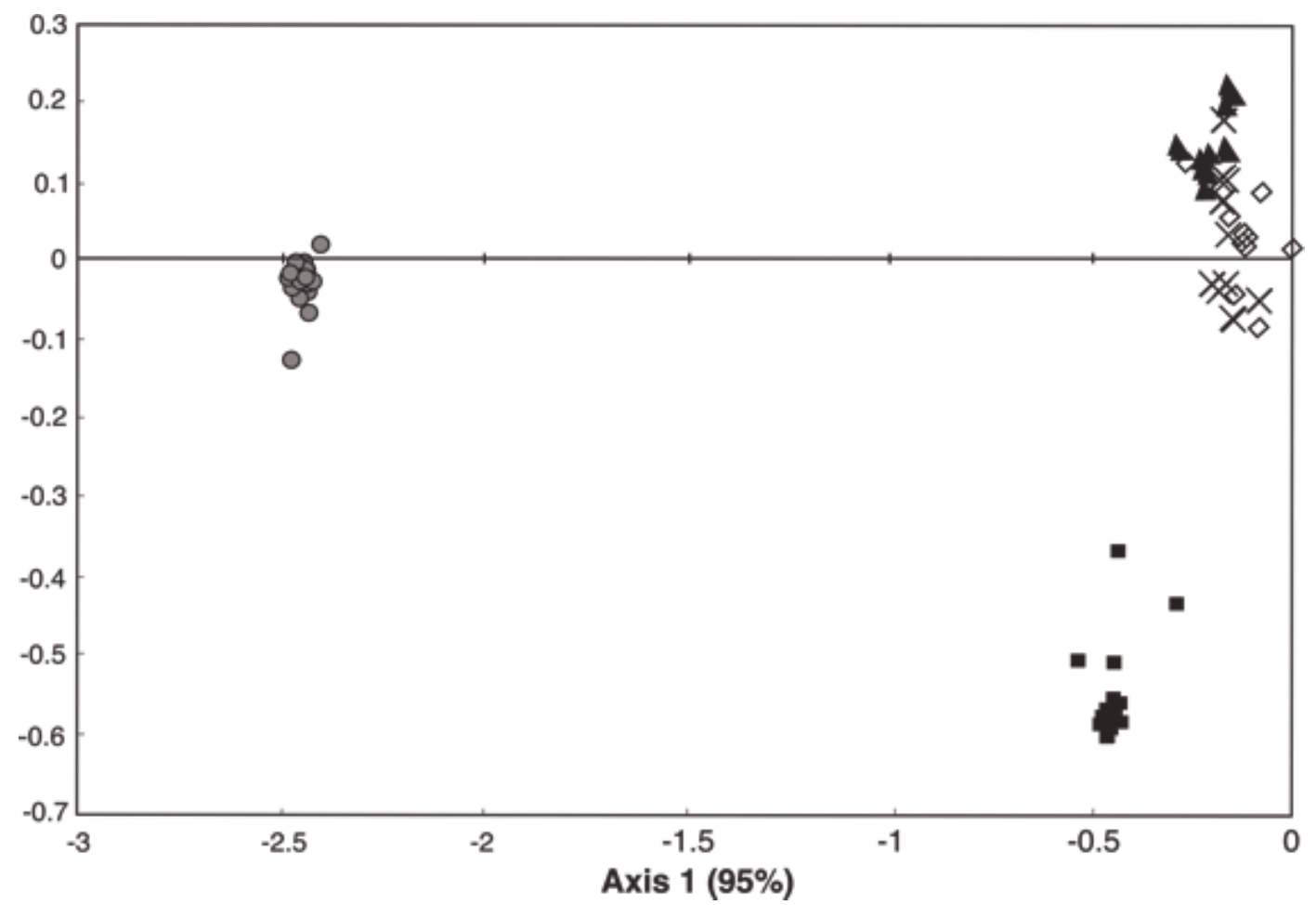

Figure 2. Canonical discriminant analysis representing the distribution of the sampling sites according to the fish fauna composition. Gamboa dos Papagaios (P1 -), Gamboa do Sucuriu (P2 - ๑), Gamboa do Baguaçu (P3 - x), Ponta do Poço (P4 - A) e Pontal do Sul (P5 - $\diamond)$. 
(Bugula neritina), octocorals (Renilla reniformis, Callipodium sp., Leptogorgia setacea), echinoderms (Luidia alternata alternata), mollusks, crustaceans, and ascidians (Clavelina oblonga). The Gamboa dos Papagaios presents smaller variety of benthic organisms, with the presence of echinoderm, mollusks, and crustaceans, and large amount of leaves. This deposition of leaves (Rhizophora mangle, Avicennia schaueriana and Laguncularia racemosa) is related to the mangrove vegetation found near the site and the low current intensities that allow its accumulation. Sites Gamboa do Baguaçu and Ponta do Poço, have a less diverse bottom cover compared to the other sites, with fewer organisms (only mollusks and crustaceans) or leaves collected. Pontal do Sul, with greater influence from the sea, has a sandy bottom, no leaves or benthic organisms were observed (Table S2).

No significant differences were however observed from major environmental variables (dissolved oxygen, seston, nutrients, and temperature) between the sampling sites (ANOVA, $p>0.05$ ), however, the means of salinity (ANOVA,
$\mathrm{F}=11.29 ; p<0.05)$ and $\mathrm{pH}$ (ANOVA, $\mathrm{F}=5.57 ; p<$ 0.05 ) were significantly different. Salinity and $\mathrm{pH}$ differed significantly among sampling sites (Tukey tests: $p<0.05)$. Pontal do Sul exhibited the highest values of salinity and the highest values of $\mathrm{pH}$ were observed in Ponta do Poço (Table S3).

The CDA showed a clustering trend with considerable overlap of the sampling sites according to environmental variables (Figure 3). The first two vectors in the CDA, were responsible for $94.95 \%$ of the data variance.

\section{DISCUSSION}

The biotic factors, as cover bottom, seem to be responsible for the composition of the fish fauna in the five sites sampled. Differences in the bottom substrate of each sampling site were evident when the variety and quantity of organic matter captured in the samples along with the fish were considered. The structuring of the estuarine fish community was largely driven by the abiotic environment (Vilar \& Joyeux 2018). In the region of sampling sites, there are higher values of temperature, salinity, $\mathrm{pH}$

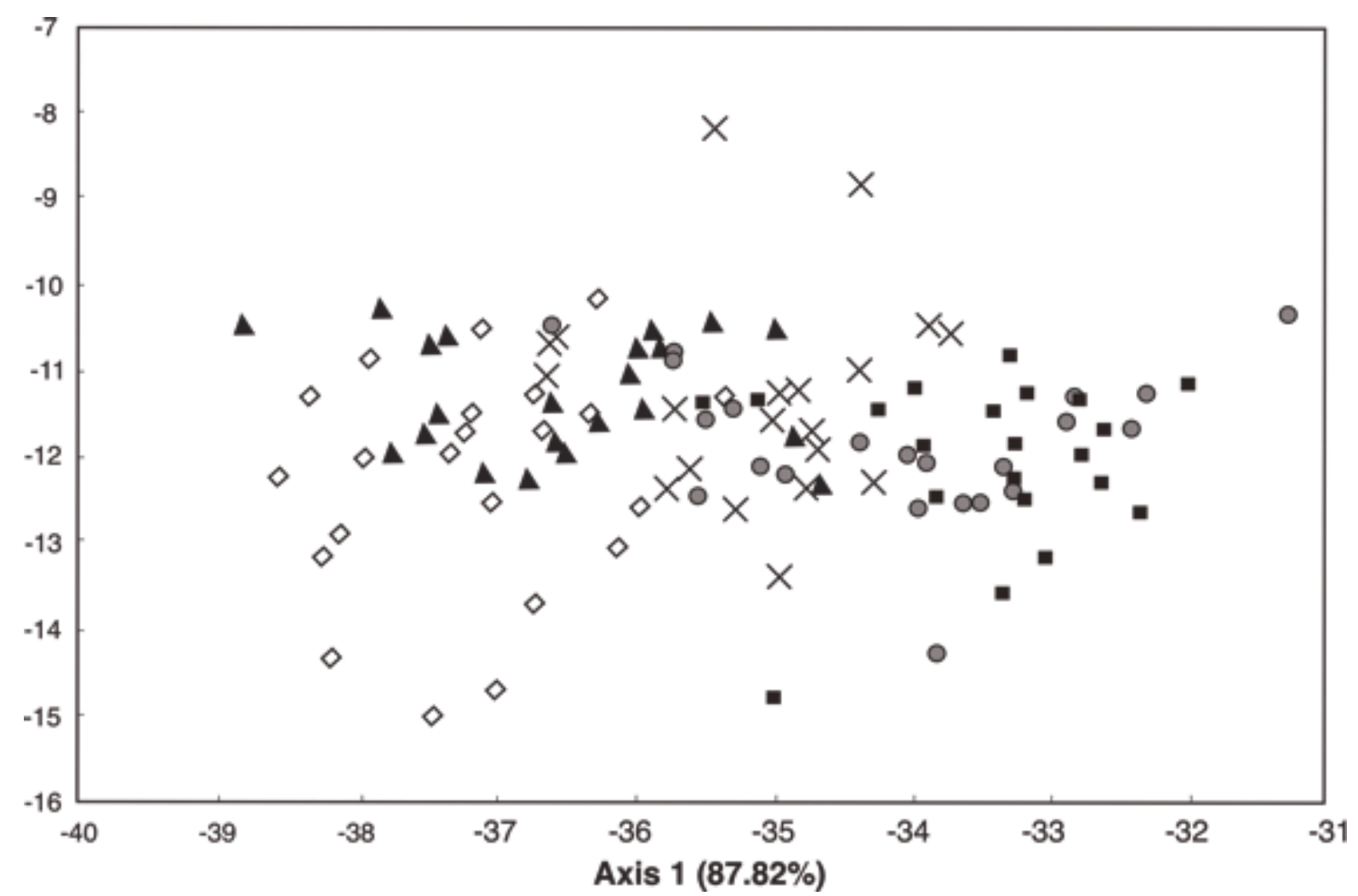

Figure 3. Canonical discriminant analysis representing the distribution of the sampling sites according to environmental variables. Gamboa dos Papagaios (P1 - a), Gamboa do Sucuriu (P2 - ๑), Gamboa do Baguaçu (P3 - ×), Ponta do Poço (P4 - ム) e Pontal do Sul (P5 - $\diamond)$. 
and dissolved oxygen compared to the innermost area of the Paranaguá Estuarine Complex (Lana et al. 2001). These environmental characteristics are due to the greater influence of marine water in estuarine mouths (Machado et al. 1997).

The sites Gamboa dos Papagaios and Gamboa do Sucuriu have complex bottom sediments, where the carbonates $\left(\mathrm{CO}_{3}\right)$ in the sediments reach values up to $20 \%$ (Lamour et al. 2004). In these sites, where the richness and number of fish caught were higher, the bottom substrate was found to be more complex. The Gamboa dos Papagaios presents large amount of leaves, where the organic matter corresponds to about $10 \%$ of the sediments (Lamour et al. 2004). This sample site is located on the vegetated area, and the mangrove tree species, such as Rhizophora mangle, has been recognized as the major contributor of organic matter in this environment (Nova et al. 2017). The diversity of communities in tropical waters is related to the complexity of the environment (Lowe-McConnell 1987). The main hypotheses for this relationship are: (1) structural heterogeneity - fish are attracted to structurally complex habitats for shelter and to prevent predation, and (2) food availability (Day et al. 1989, Edgar \& Shaw 1995, Laegdsgaard \& Johnson 2000).

There are differences in bottom sediments at each sampling site, where the mineral sediments (siliciclastic rock fragments) are mixed with organic ones (carbonatic and vegetal) in different proportions, driven by local dynamics. The differences in the bottom structure found in the five sampling sites are mainly due to the current intensity. Gamboa dos Papagaios and Gamboa do Sucuriu are located in more sheltered areas where the currents are less intense, favoring the establishment of a rich benthic community, unlike that observed in the areas most exposed to the currents (Gamboa do Baguaçu, Ponta do Poço and Pontal do Sul) (Lamour et al. 2004).

The correlation observed in the canonical discriminant analysis of the environmental parameters between sampling sites, indicated a little influence in the distribution of the species, showed a gradient between innermost areas (Gamboa dos Papagaios and Gamboa do Sucuriu), and the external areas (Ponta do Poço and Pontal do Sul). The innermost areas showed higher values of phosphate, which may be of allochthonous (pollution and leaching) and autochthonous (decomposition) origin. The salinity and the dissolved oxygen showed higher values in the external areas, under stronger marine influence. The first two vectors in the discriminant analysis, representing the distribution of the sampling sites according to environmental variables, were responsible for $94.95 \%$ of the data variance. The vector 1 , responsible for $87.82 \%$ of the variance, is positively related to phosphate and negatively related to oxygen and salinity. Salinity was the main factor structuring the fish assemblage in several estuarine systems (Catelani et al. 2014).

Salinity and dissolved oxygen presented the expected behavior. There was a salinity gradient with higher values in the outermost areas, where the influence of marine water is stronger, in relation to the innermost areas. Similarly, the marine water, which was more oxygenated, had influence on the concentrations of dissolved oxygen registered in the sampling sites (Machado et al. 1997, Elliot \& Hemingway 2002).

Allochthonous phosphate may be a product of the intense human activities in the PEC, where urban, port, industrial and dredging activities coexist, among many others; or may be transported to the estuary through rivers (Odum 1988). Phosphate of autochthonous origin results from the decomposition of organic matter, and for this reason it is considered a direct indicator of its presence in the environment. The sites Gamboa dos Papagaios and Gamboa do Sucuriu were more influenced by the phosphate concentrations in relation to the other sites. These are more internal areas, near the middle region of the PEC, where the highest values of phosphate of the bay were recorded (Machado et al. 1997).

The areas of Gamboa dos Papagaios and Gamboa do Sucuriu are located more internally in the bay. Therefore, they are more exposed to the pollution from the Paranaguá municipality, besides the diverse industries and other cities found in the region. At these sites, large amounts of organic material (organisms and leaves), whose decomposition has phosphate, among other nutrients, as a product, were also recorded. Despite this, it is important to note that phosphate can cause eutrophication, which threatens the structure and function of coastal ecosystems through the induction of bloom of toxic algae, deposition of 
organic matter resulting in anoxic waters, changes in trophic structures and reduction of diversity (Rabalais et al. 1996, Dortch et al. 2001, Cugier et al. 2005).

The differences found in the fish fauna between the sites were due to the proportion in which the species occurred in each area. The species Achirus lineatus, Chaetodipterus faber, Chilomycterus spinosus spinosus, Diplectrum radiale, Hippocampus reidi, Sphoeroides greeleyi, Sphoeroides testudineus and Stephanolepis hispidus were found in large quantities in Gamboa do Sucuriu relative to the other sites (Spach et al. 2003). In Gamboa dos Papagaios, the most representative species were Achirus lineatus, Ctenosciaena gracilicirrhus, Micropogonias furnieri, Rypticus randali, and Symphurus tesselatus, with a higher proportion of Achoviella lepidentostole and Chloroscombrus chrysurus in Gamboa do Baguaçu and Pontal do Sul, respectively. Few species were relatively abundant in all sampling sites, Anisotremus surinamensis, Eucinostomus argenteus, Etropus crossotus and Prionotus punctatus.

Citharichthys sp. occurred in all sample sites. There are three species of this genus present in the region: C. arenaceus $C$. macrops and $C$. spilopterus (Spier et al. 2018). Recent studies have also found Cathorops spixii abundantly (Possatto et al. 2017). Sciaenidae and Engraulidae are the families with high number of species in many estuarine ecosystems, as well as Ariidae, in terms of abundance (Reis-Filho et al. 2010, Osório et al. 2011, Catelani et al. 2014, Vilar \& Joyeux 2018).

The presence of the seahorse (Hippocampus reidi), classified as vulnerable in Brazil and near threatened globally (Oliveira \& Pollom 2017), almost exclusively in Gamboa do Sucuriu (27 individuals in Gamboa do Sucuriu, one in Gamboa do Baguaçu and absent in other sites) illustrates how a more complex substrate provides microhabitats that allow for the increase in fish diversity (Kennish 1990, Ferreira et al. 2001). The macrobenthic communities of mangroves in PEC are numerically dominated by crabs, polychaetes, and bivalves (Lana et al. 2001). It is known that seahorses occur in associations with complex habitats such as roots in mangroves, marsh, macroalgae and reefs, usually using the tail to attach to the substrate (Rosa et al. 2002).
The spiny pufferfish (Chilomycterus spinosus spinosus), which was relatively more abundant in the Gamboa do Sucuriu, is also considered a species whose occurrence is associated with reefs (Rodrigues-Barreto et al. 2017). Omnivores are best represented in places where there is a large variety of sessile invertebrates, and consequently offer a greater variety of food (Ferreira et al. 2001). A good example of an omnivore is the planehead filefish (Stephanolepis hispidus), which was found in large numbers in Gamboa do Sucuriu, and feeds on benthic algae, cnidarians and the most varied types of invertebrates (Mancera-Rodríguez \& CastroHernández 2015).

In the sites Gamboa do Baguaçu and Ponta do Poço, the bottom structure found was less diverse, with few organisms or leaves collected. At these sites, there were high values for diversity and low number of individuals were caught, demonstrating that the diversity depended more on evenness than on the number of species. Pontal do Sul, with less fish diversity then other samples sites, had a flat and sandy bottom. Sediments in the higher energy and euhaline sector of PEC are mainly well-sorted fine sand, with low organic content (Faraco \& Lana 2003, Lamour et al. 2004).

It was possible to identify assemblages with distinct patterns of habitat use, along the transition zone from tropical mangroves to temperate salt marshes (Faraco \& Lana 2003). The proximity to the mouth of sample sites favored marine stragglers (22 species), but resident estuarine (16 species) and marine migrants (12 species), were found in all sites with higher abundances (Reis-Filho et al. 2010, Osório et al. 2011, Favero et al. 2019).

Fishery and tourism are the economic base of the local communities. The region it houses an important harbor's area in southern Brazil (Antonina and Paranaguá). Paranaguá is one of the largest ports for grain exporting in Latin America (Santos et al. 2009). Environmental alteration is the major cause of impact on fish populations in estuaries (Blaber et al. 2000). In order to minimize the impacts of anthropogenic activities in the region, there are rights and duties for society to use the natural resources that the PEC provides, for example, there are a mosaic of conservation units, including marine and terrestrial units of restricted and sustainable use (Lana et al. 2001). The sample sites, mainly Gamboa dos Papagaios and Gamboa 
do Sucuriu, are inserted in a well-preserved mangrove area. Mangroves are one of the most endangered and important biological ecosystems, offering various environmental and economic services (Hussan \& Bardolla 2008, Romañach et al. 2018). The National Conservation Action Plan of Endangered Species and of Socioeconomic Importance in Mangrove Ecosystems (PAN Mangrove 2015), serves as a "guide" for the society to planning the sustainable development with for conserve the biological diversity and the cultural integrity in the region of PEC.

The National Environment Ministry published the Ordinance 445, guiding the fishing sector to adopt mitigation or preventive measures for some species (MMA 2014). Most of the fish have not been evaluated according to national conservation status (MMA 2014), only Gymnothorax ocellatus as data deficient, and Hippocampus reidi as vulnerable. Forty-nine species were on the red list of the International Union for Conservation of Nature (IUCN, 2020), in which 43 are classified as of least concern, and four species as data deficient. Hippocampus reidi and Pseudobatos percellenswere classified as near threatened; both are considered as species of economic importance in aquarium trade and as a fishery resource, respectively (Spier et al. 2018).

We emphasize that there is a huge gap in the basic ecological knowledge of most of the listed species, a fact evidenced in the fauna extinction assessments based on IUCN red list of threatened species criteria, with a large part of the species considered not evaluated or data deficient (MMA 2014). Thus, there is a great demand for bioecological studies (e.g. populational, age and growth, reproduction, feeding) to be carried out, and these data collected 20 years ago, including the identification of priority habitats along the estuarine fishes' distribution areas, must serving as a basis for current studies.

This study evidence the influence of the habitat structural complexity in the diversity and abundance of estuarine fish fauna. This is important information that should be considered to optimize programs for the management and conservation of local resources of the Paranaguá Bay estuarine complex in Brazil.

\section{ACKNOWLEDGMENTS}

J.A.A. and O.R.C acknowledge individual scholarship grants from Brazilian Agency for Support and Evaluation of Graduate Education (CAPES). The authors are also grateful to the Center of Studies of the Sea for sampling support. We also thank the anonymous reviewers for their valuable comments.

\section{REFERENCES}

Alofs, K. M., \& Polivka, K. M. 2004. Microhabitatscale influences of resources and refuge on habitat selection by an estuarine opportunist fish. Marine Ecology Progress Series, 271, 297306.

Barbier, E. B., Hacker, S. D., Kennedy, C., Koch, E., Stier, A. C., \& Silliman, B. R. 2011. The Value of Estuarine and Coastal Ecosystem Services. Ecological Monographs, 81,169-193.

Barletta, M., \& Blaber, S. J. M. 2007. Comparison of Fish Assemblages and Guilds in Tropical Habitats of the Embley (Indo-West Pacific) and Caeté (Western Atlantic) Estuaries. Bulletin of Marine Science 80, 647-680.

Blaber, S. J. M., Cyrus, D. P., Albaret, J. J., Ching, C. V., Day, J. W. Elliott, M., \& Silvert, W. 2000. Effects of fishing on the structure and functioning of estuarine and nearshore ecosystems. ICES Journal of Marine Science, 57(3), 590-602.

Briggs, J. C., \& Bowen, B. W. 2012. A realignment of marine biogeographic provinces with particular reference to fish distributions. Journal of Biogeography, 39,12-30.

Catelani, P. A., Petry, A. C., Di Dario, F., dos Santos, V. L. M., \& Mincarone, M. M. 2014. Fish composition (Teleostei) of the estuarine region of the Macaé River, southeastern Brazil. Check List, 10(4), 927-935.

Cattani, P., \& Lamour, M. R. 2016. Considerations Regarding Sedimentation Rates along the E-W Axis of the Paranaguá Estuarine Complex, Brazil: A Bathymetric Approach. Journal of Coastal Research, 32(3), 619-628.

Cattani, A. P., Ribeiro, G. C., Hostim-Silva, M., Soeth, M., Clezar, L., Cardoso, O. R., Pichler, H. A., \& Spach, H. L. 2020. Spatial and temporal differences in the fish assemblage structure in 
a subtropical estuary. Latin american journal of aquatic research, 48(1), 74-84.

Cugier, P., Billen, G., Guillaud, J. F., Garnier, J., \& Ménesguen, A. 2005. Modelling the eutrophication of the Seine Bight (France) under historical, present and future riverine nutrient loading. Journal of Hydrology, 304, 381-396.

Day, J. W., Hall, C. A. S., Kemp, W. M., \& YáñezAraciba, A. 1989. Estuarine Ecology. Nova York: John Wiley \& Sons: p.77.

Dortch, Q., Rabalais, N. N., Turner, R. E., \& Qureshi, N. A. 2001. Impacts of changing $\mathrm{Si} / \mathrm{N}$ ratios and phytoplankton species composition. In: Rabalais, N. N. \& Turner, R. E. (Eds.), Coastal Hypoxia: Consequences for Living Resources and Ecosystems. pp. 37-48. Washington, DC: American Geophysical Union.

Edgar, G. J., \& Shaw, C. 1995. The production and trophic ecology of shallow-water fish assemblages in southern Australia III. General relationships between sediments, seagrasses, invertebrates and fishes. Journal of Experimental Marine Biology and Ecology, 194(1), 197-131.

Elliott, M., \& Hemingway, K. L. 2002. Fishes in estuaries. Oxford, Blackwell Science Ltd., p. 636.

Elliott, M. Whitfield, A. K., Potter, I. C., Blaber, S. J. M., Cyrus, D. P., Nordlie, F. G., \& Harrison, T. D. 2007. The guild approach to categorizing estuarine fish assemblages: a global review. Fish and Fisheries. 8, 241-268.

Elliott, M., \& Whitfield, A. K. 2011. The Estuarine Ecosystem Ecology, Threats, and Management. Estuarine, Coastal and Shelf Science, 94, 306314.

Faraco, L. F. D., \& Lana, P. C. 2003. Response of polychaetes to oil spills in natural and defaunated subtropical mangrove sediments from Paranaguá bay (SE Brazil). In: Sigvaldadóttir, E., Mackie, A. S. Y., Helgason, G. V., Reish, D. J., Svavarsson, J., Steingrímsson, S. A., Guðmundsson, G. (Eds.). Advances in Polychaete Research, p. 321-328. Springer, Dordrecht.

Favero, F. D. L. T., da Silva Araujo, I. M., \& Severi, W. 2019. Structure of the fish assemblage and functional guilds in the estuary of Maracaípe, northeast coast of Brazil. Boletim do Instituto de Pesca, 45(1), e.417.
Ferreira, C. E. L., Gonçalves J. E., \& Coutinho, R. 2001. Community structure of fishes and habitat complexity on a tropical rocky shore. Environmental Biology of Fishes, 61(4), 353369.

Figueiredo, J. L., \& Menezes, N. A. 1978. Manual dos peixes marinhos do Sudeste do Brasil. II. Teleostei (1). Universidade de São Paulo, São Paulo. p. 110.

Figueiredo, J. L., \& Menezes, N. A. 1980. Manual dos peixes marinhos do Sudeste do Brasil. III. Teleostei (2). Universidade de São Paulo, São Paulo. p. 90.

Figueiredo, J. L., \& Menezes, N. A. 2000. Manual dos peixes marinhos do Sudeste do Brasil. VI. Teleostei (5). Universidade de São Paulo, São Paulo. p. 116.

Fricke, R., Eschmeyer, W. N., \& van der Laan, R. 2020. Eschmeyer's catalog of fishes: genera, species, references. Retrieved on May 15, 2020, from http://researcharchive.calacademy.org/ research/ichthyology/catalog/fishcatmain.asp

Froese, R., \& Pauly, D. 2020. World Wide Web electronic publication. Retrieved on May 15, 2020. Retrieved from http://www.fishbase.org

Grasshoff, K. A., Ehrhardt, M., \& Kremling, K. 1983. Methods of seawater Analisys. 2nd ed. Weinheim; Deerfield Beach: Verlag chemiep. 419.

Hussan, S. A., \& Bardola, R. 2008. Valuing mangrove ecosystem services: linking nutrient retention function of mangrove forests to enhanced agroecosystem production. Wetlands Ecology and Management, 16(6): 441-450.

IUCN. 2020. The IUCN red list of threatened species. International ed. IUCN Global Species Programme Red List Unit. Retrieved on May 23, 2020, from http://www.iucnredlist.org/

Kennish, M. J. 1990. Ecology of estuaries. Boston: CRC Press: p. 391.

Laegdsgaard, P., \& Johnson, C. 2000. Why do juvenile fish utilize mangrove habitats? Journal of Experimental Marine Biology and Ecology, 257(2), 229-253.

Lamour, M. R., Soares, C. R., \& Carrilho, J. C. 2004. Mapas de parâmetros texturais de sedimentos de fundo do complexo estuarino de Paranaguá - PR. Boletim Paranaense de Geociências, 55(1), 77-82.

Lamour, M. R., Angulo, R. J., \& Soares, C. R. 2007. 
Bathymetrical Evolution of Critical Shoaling Sectors on Galheta Channel, Navigable Access to Paranaguá Bay, Brazil. Journal of Coastal Research, 23(1), 49-58.

Lana, P. C., Marone, E., Lopes, R. M., \& Machado, E. C. 2001. The Subtropical Estuarine Complex of Paranaguá Bay, Brazil. In: U. Seeliger \& B. Kjerfve (Eds.). Coastal Marine Ecosystems of Latin America. Ecological Studies (Analysis and Synthesis). pp. 131-145. Berlin: Springer.

Legendre, L., \& Legendre, P. 1983. Numerical ecology. Developments in environmental modelling, 3. Amsterdam: Elsevier Science: p. 419.

Lessa, G. C., Angulo, R. J., Giannini, P. C. F., \& Araújo, A. D. 2000. Stratigraphy and Holocene evolution of a regressive barrier in south Brazil. Marine Geology, 165(1-4), 87-108.

Lowe-McConnell, R. H. 1987. Ecological studies in tropical Fishes Communities. New York: Cambrige University Press: p. 391.

Machado, E. C., Daniel, C. B., Brandini, N., \& Queiroz, R. L. V. 1997. Temporal and spatial dynamics of nutrients and particulate suspended matter in Paranaguá Bay, PR, Brazil. Nerítica, 11(1), 15-34.

Mancera-Rodriguez, N. J., \& Castro-Hernandez, J. J. 2015. Feeding ecology of the planehead filefish Stephanolepis hispidus (Pisces: Monacanthidae), in the Canary Islands area. Revista de Biología Marina y Oceanografía, 50(2), 221-234.

Mantovanelli, A., Marone, E., Da Silva, E. T., Lautert, L. F., Klingenfuss, M. S., Prata Jr., V. P., Noernberg, M. A., Knoppers, B. A., \& Angulo, R. J. 2004. Combined tidal velocity and duration asymmetries as a determinant of water transport and residual flow in Paranaguá Bay estuary. Estuarine, Coastal and Shelf Science, 59(4), 523-537.

Menezes, N. A., \& Figueiredo, J. L. 1980. Manual de peixes marinhos do Sudeste do Brasil. IV. Teleostei (3). Universidade de São Paulo, São Paulo. p. 96.

Menezes, N. A., \& Figueiredo, J. L. 1985. Manual de peixes marinhos do Sudeste do Brasil. V. Teleostei (4). Universidade de São Paulo, São Paulo. p. 105.

MMA. 2014. Portaria No 445 de 17 de dezembro de 2014.

Nêmes, D. D., \& Marone, E. 2013. Caracterização das ondas de superfície na plataforma interna do litoral do Estado do Paraná, Brasil. Boletim Paranaense de Geociências, 68-69(2013), 12-25.

Netto, S. A., \& Lana, P. C. 1997. Intertidal zonation of benthic macrofauna in a subtropical salt marsh and nearby unvegetated flat (SE Brazil). Hydrobiologia, 353, 171-180.

Noernberg, M. A., Lautert, L. F. L., Araújo, A. D., Marone, E., Angelotti, R., Netto, J. P. B., \& Krug, L. A. 2004. Remote sensing and GIS integration for modeling the Paranaguá Estuarine ComplexBrazil. Journal of Coastal Research, 39, 16271631.

Nova, F. V. P. V., Torres, M. F. A., \& Coelho, M. P. 2017. Composição físico-química de solos em espécies arbóreas do ecossistema manguezal. ACTA Geográfica, 11(27), 1-19.

Odum, E. P. 1988. Ecologia. Rio de Janeiro: Editora Guanabara: p.434.

Oliveira, T., \& Pollom, R. 2017. Hippocampus reidi. The IUCN Red List of Threatened Species 2017:.T10082A17025021. Retrieved on July 20, 2019, from http://dx.doi.org/10.2305/ IUCN.UK.2017-3.RLTS.T10082A17025021.en

Osório, F. M., Godinho, W. O., \& Lotufo, T. M. D. C. 2011. Ictiofauna associada às raízes de mangue do estuário do Rio Pacoti-CE, Brasil. Biota Neotropica, 11(1), 415-420.

Passos, A. C. D., Contente, R. F., Araujo, C. C. V. D., Daros, F. A. L. D. M., Spach, H. L., Abilhôa, V., \& Fávaro, L. F. 2012. Fishes of Paranaguá estuarine complex, south west Atlantic. Biota Neotropica, 12(3), 226-238.

Possatto, F. E., Broadhurst, M. K., Gray, C. A., Spach, H. L., \& Lamour, M. R. 2017. Spatiotemporal variation among demersal ichthyofauna in a subtropical estuary bordering World Heritagelisted and marine protected areas: implications for resource management. Marine and Freshwater Research, 68(4), 703-717.

Potter, I. C., Tweedley, J. R., Elliott, M., \& Whitfield, A. K. 2015. The Ways in Which Fish Use Estuaries: A Refinement and Expansion of the Guild Approach. Fish and Fisheries, 16, 230-239.

Rabalais, N. N., Turner, R. E., Justic', D., Dortch, Q., Wiseman W. J., \& Sen Gupta, B. K. 1996. Nutrient changes in the Mississippi River and system responses on the adjacent continental shelf. Estuaries, 19(2), 386-407.

Reis-Filho, J. A., Nunes, J. D. A. C. D., \& Ferreira, A. 
2010. Estuarine ichthyofauna of the Paraguaçu river, Todos os Santos Bay, Bahia, Brazil. Biota Neotropica, 10(4), 301-311.

Rodrigues-Barreto, N., Shimada-Brotto, D. V., Guterres-Giordano, R., Andrade-Bertoncini, A., \& Dos Santos, L. N. 2017. The rocky reef fishes of Vermelha Beach, a marine-estuarine transitional zone at Guanabara Bay, Brazil. Latin American Journal of Aquatic Research, 45(1), $33-40$.

Romañach, S. S., DeAngelis, D. L., Koh, H. L., Li, Y., Teh, S. Y., Barizan, R. S. R., \& Zhai, L. 2018. Conservation and restoration of mangroves: Global status, perspectives, and prognosis. Ocean \& Coastal Management, 154, 72-82.

Rosa, I. L., Dias, T. L., \& Baum, J. K. 2002. Threatened fishes of the world: Hippocampus reidi Ginsburg, 1933 (Syngnathidae). Environmental Biology of Fishes, 64(4), 378-378.

Santos, D. M., Araújo, I. P., Machado,E.C., CarvalhoFilho, M. A., Fernandez, M. A., Marchi, M. R., \& Godoi, A. F. L. 2009. Organotin compounds in the Paranaguá Estuarine Complex, Paraná, Brazil: Evaluation of biological effects, surface sediment, and suspended particulate matter. Marine Pollution Bulletin, 58(12), 1926-1931.

Shannon, C. E., \& Weaver, W. 1963. The mathematical theory of communication. Illinois: University of Illinois Press: p. 146.

Spach, H. L., Santos, C., \& Godefroid, R. S. 2003. Padrões temporais na assembléia de peixes na gamboa do Sucuriú, Baía de Paranaguá, Brasil. Revista Brasileira de Zoologia, 20(4), 591-600.

Spier, D., Gerum, H. L. N., Bornatowski, H., Contente, R., Mattos, N. A., Vilar, C. C., \& Spach, H. L. 2018. Ichthyofauna of the inner shelf of Paraná, Brazil: checklist, geographic distribution, economic importance and conservation status. Biota Neotropica, 18(2), e20170385.

Strickland, J. L. H., \& Parsons T. R. 1972. A Practical Handbook of Seawater Analysis. Ottawa: Fisheries Research Board of Canada: p. 310.

UNESCO. 1999. World Heritage List: Atlantic Forest South-East Reserves. United Nations Educational, Scientific and Cultural Organization. Retrieved on August 2, 2019, from http://whc.unesco.org/en/list/893

Vilar, C. C., Spach, H. L., \& Joyeux, J. C. 2011. Spatial and temporal changes in the fish assemblage of a subtropical estuary in Brazil: environmental effects. Journal of the Marine Biological Association of the United Kingdom, 91(3), 635-648.

Vilar, C. C., \& Joyeux, J. C. 2018. Synopsis of the knowledge on the Brazilian estuarine fishes. PeerJ, 6, e27085v1.

Zar, J. H. 1996. Biostatistical analysis. 3nd ed. New Jersey: Prentice Hall: p. 662.

\section{Supplementary Material.}

Table S1. Fish fauna captured in the Paranaguá Bay Complex, absolute abundance at sampling sites, total $(\mathrm{N})$ and relative (\%) abundance. Sampling sites: Gamboa dos Papagaios (P1), Gamboa do Sucuriu (P2), Gamboa do Baguaçu (P3), Ponta do Poço (P4) e Pontal do Sul (P5). Habitat use $(\mathrm{HU}): \mathrm{MS}=$ marine stragglers; $\mathrm{ER}=$ estuarine residents; $\mathrm{MM}=$ marine migrants; $\mathrm{EM}=$ estuarine migrants; and SC = semi-catadroms. Geographic Distribution (GD): CT = Circuntropical, $\mathrm{TA}=$ Trans Atlantic, WA $=$ Western Atlantic, SWA $=$ Southern West Atlantic, SSWA = Southern Southwest Atlantic, $\mathrm{CA}=$ Caribbean, $\mathrm{BR}=$ Brazilian Province and EP = Eastern Pacific. National (MMA) and global (IUCN) conservation status: $\mathrm{NE}=$ not evaluated, $\mathrm{LC}=$ least concern, $\mathrm{NT}=$ near threatened, $\mathrm{DD}=$ data deficient, $\mathrm{VU}=$ vulnerable, $\mathrm{EN}=$ endangered and $\mathrm{CR}=$ critically endangered.

TableS2. Qualitative description of the bottom cover at each sampling site. Presence (x) and absence (-) of items. Fish assemblage data (abundance, richness, and diversity index). Sampling sites: Gamboa dos Papagaios (P1), Gamboa do Sucuriu (P2), Gamboa do Baguaçu (P3), Ponta do Poço (P4) e Pontal do Sul (P5).

TableS3. Mean and standard error of environmental variables [Temperature $\left({ }^{\circ} \mathrm{C}\right)$, salinity, dissolved oxygen $(\mathrm{ml} / \mathrm{L}), \mathrm{pH}$, seston $(\mathrm{mg} / \mathrm{L})$, phosphate $(\mu \mathrm{M})$, total nitrogen $(\mathrm{mg} / \mathrm{L})$, and silicate $(\mu \mathrm{M})]$ from sampling sites. Different letters indicate statistically significant differences (Tukey tests, $p<$ 0.05). *Significant values (ANOVA, $p<0.05$ ).

Submitted: 26 August 2019

Accepted: 1 August 2020

Published on line: 19 August 2020

Associate Editor: Diego Garcia 